\section{International Scientific Journal Theoretical \& Applied Science}

p-ISSN: 2308-4944 (print) $\quad$ e-ISSN: 2409-0085 (online)

Year: 2015 Issue: 09 Volume: 29

Published: $30.09 .2015 \quad \underline{\text { http://T-Science.org }}$

SECTION 26. Medicine.
Vyacheslav Kanshaubievich Kumykov

Associate Professor, PhD,

Kabardin-Balkar state university,

Nalchik, Russian Federation

koumykov@hotmail.com

Muaed Muzafarovich Oshkhunov

Professor, PhD,

Kabardin-Balkar state university, Nalchik, Russian Federation

Zalina Khasanovna Abazova Associate Professor, PhD,

Kabardin-Balkar state university,

Nalchik, Russian Federation

Marina Kilostanovna Efendieva

Physician, Medical center SEM,

Nalchik, Russian Federation

\title{
ON ONE METHOD OF SCALE EXAMINATIONS OF THYROID GLAND CONDITION
}

Abstract: On the base of brief review of domestic and foreign papers, devoted to the methods of express diagnostics of thyroid gland pathologies, a new version of reflex meter is suggested. The data of scale examinations of thyroid gland condition of students in the age from 16 till 18 years are also presented.

Key words: thyroid gland, reflex meter, screening test.

Language: English

Citation: Kumykov VK, Oshkhunov MM, Abazova ZK, Efendieva MK (2015) ON ONE METHOD OF SCALE EXAMINATIONS OF THYROID GLAND CONDITION. ISJ Theoretical \& Applied Science 09 (29): 36-40.

Soi: http://s-o-i.org/1.1/TAS-09-29-9 Doi: crossef http://dx.doi.org/10.15863/TAS.2015.09.29.9

\section{Introduction}

There is a great need for a simple test of thyroid function state which can be used in clinical practice and in peripheral hospitals where other methods are not available. Tendon-reflex timing which gives an immediate result is the method which has been used increasingly in 70-s - 90-s of past century as an index of thyroid function [1-3]. In general, reflex times correlate well with hormone estimations.

\section{Discussion of the method}

It is generally accepted that the tendon reflexes are shortened in the majority of patients with hyperthyroidism and prolonged in the case of hypothyroidism. Chaney was the first who recorded the Achilles tendon reflex and proved what had previously detected clinically [4].

Since then various techniques were developed for the ankle-jerk timing. One of them was the method used by Lawson [5, 6], in which the anklejerk is timed with the use of a magnet attached to the sole, movement of which generates current in an inductive coil recording directly on an electrocardiograph. Before testing starts a horseshoe magnet is strapped to the sole of the patient foot under the arch.

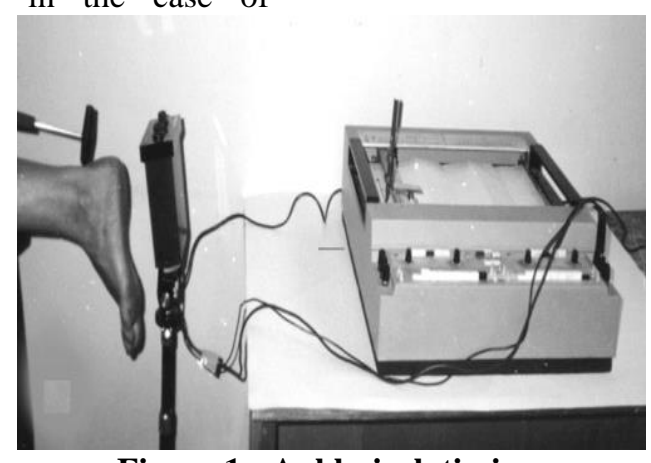

Figure 1 - Ankle-jerk timing. 
The gist of the method is following. The subject kneeling on a chair, a horseshoe magnet is strapped to the sole of the foot under the arch at $2 \mathrm{~cm}$. distant, twin induction coils are placed and connected to two leads of a portable electrocardiograph (Fig. 1).

Duration of a tendon reflex is calculated indirectly dividing the length of the diagram projection on horizon axe by the paper speed of electrocardiograph.

This apparatus are widely used in clinical practice because of its simplicity and convenience [7 - 14]. A diagrammatic representation of typical tracing is shown on Figures 2, 3. [12].

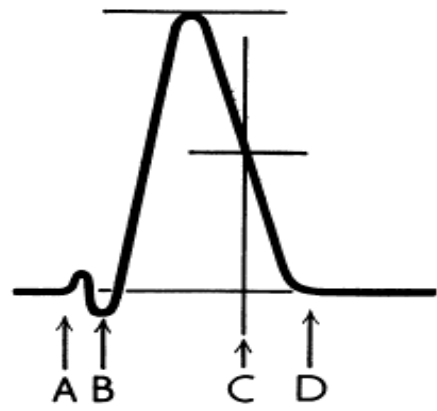

Figure 2 - Diagrammatic representation of a typical tracing.

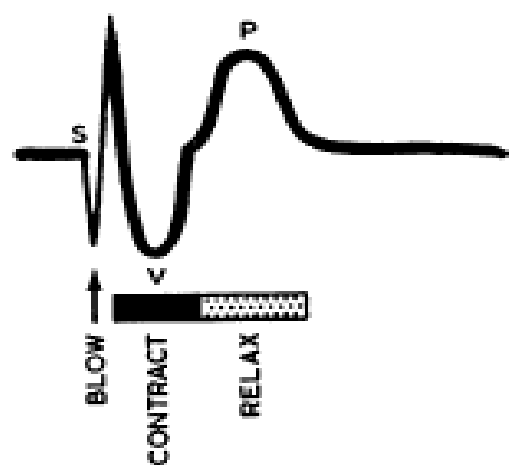

Figure 3 - Diagrammatic representation of the ankle-jerk, showing the contraction and relaxation phases.

\section{Discussion of the tracings}

The obtained tracing consists of initial part due to the hammer striking the tendon, beginning at point $\mathrm{S}$, followed by a slower downward deflection caused by muscle contraction, and a final upward deflection representing relaxation. Then follows the valley designed by point $\mathrm{V}$ and the peak $\mathrm{P}$.

Initially the distances SP, SD (D being the point where the line VP crosses the isoelectric line), and VP were measured. However, D is variable and often difficult to identify. The interval VP was the best in determining patients with thyroid disease from the control group. The VP interval is that between maximal rate of contraction and maximal rate of relaxation is an index characterizing the muscle response.

Although many authors have confirmed Chaney's original findings, the value of measuring the Achilles tendon reflex as an index of thyroid function is still in doubt.

The method raised some conflict of opinions about the value of this test because of poor reproducibility and accuracy of times obtained. Most contradictions arise in the question of interpretation of complicated diagram and determining the real time of tendon reflex duration. This is a source of errors and divergence of data obtained by different authors. Some of them measure the interval between maximal rate of contraction and maximal rate of relaxation. Others measure the time from the blow on the tendon to the point of half-relaxation, including the latent period.

High measuring error and significant spread of results are also due to the reflex meter construction, when Achilles tendon reflex time is measured indirectly using the electrocardiograph. Therefore, this measurement is interfered with mechanical artifacts caused by hammer strike of the tendon. This reduces the reliability of the results [15].

\section{Suggested method}

The goal of this work was to develop a direct method for measuring the reflex time of the knee jerk 


\begin{tabular}{|c|c|c|c|c|c|}
\hline Impact Factor: & $\begin{array}{l}\text { ISRA (India) } \\
\text { ISI (Dubai, UAF } \\
\text { GIF (Australia) } \\
\text { JIF }\end{array}$ & $\begin{array}{l}=1.344 \\
=0.829 \\
=0.356 \\
=1.500\end{array}$ & $\begin{array}{l}\text { SIS (USA) } \\
\text { PИНЦ (Russia } \\
\text { ESJI (KZ) } \\
\text { SJIF (Morocco }\end{array}$ & $\begin{array}{l}=0.912 \\
=0.179 \\
=1.042 \\
=2.031\end{array}$ & ICV (Poland) \\
\hline
\end{tabular}

in patients with thyroid pathologies, its clinical testing.

It is known that thyroid disorders bring change of all reaction times, including a knee joint reflex, which is a representative physiological parameter [20 - 23]. However, because of absence of corresponding instruments, the time of knee joint reflex is tested only qualitatively [16 - 19].

In present work, a direct method and device for high-accuracy measurement of the reflex time of the knee jerk in norm and pathology is suggested.

The method is based on the use of a reflex meter consisting of three basic elements: an electronic stopwatch timer and devices for remote switch-on and switch-off of the timer. The electronic stopwatch timer provides the time measuring with an error not more than 1 millisecond. On fig. 4 the scheme of measuring is shown. Here 1 - the electronic stopwatch timer; 2, 3 - connecting wires; 4 - remote switch on device, 5 - remote switch-off device. The switch on device is a contact knob installed in neurological hammer. At the moment of hammer blow the knob switches the timer.

The switch off device is the same kind of knob installed to a toe-cap attachment. Before the test starts the toecap attachment points to such position so that the knob plants against barrier, for example to the side of the table.

After the blow due to the reflex movement the foot pushes the knob which stops the timer. The timer measures the reflex duration, which allows the thyroid gland state estimation.

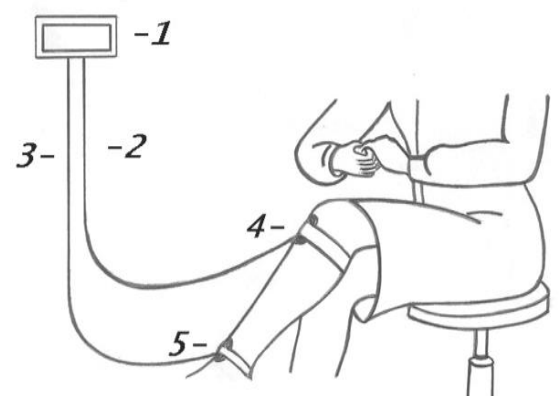

Figure 4 - Knee-jerk timing.

After the blow due to the reflex movement the foot pushes the knob which stops the timer. The timer measures the reflex duration, which allows the thyroid gland state estimation.

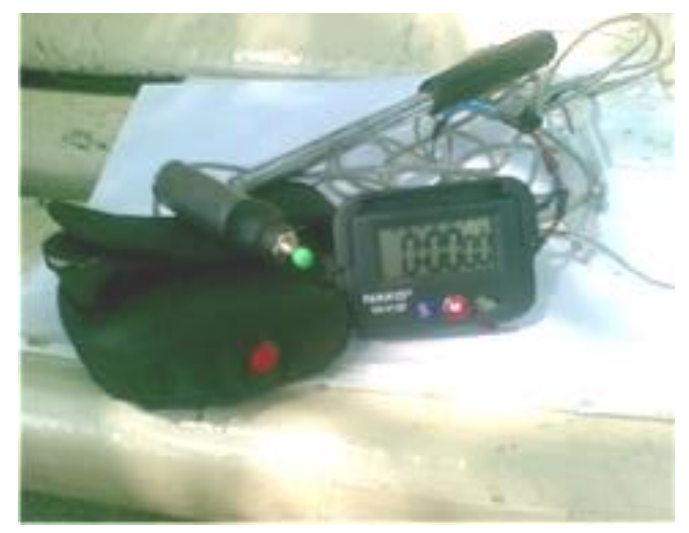

Figure 5 - The photo of knee-jerk reflex meter. 


\begin{tabular}{|c|c|c|c|c|c|c|}
\hline Impact Factor: & $\begin{array}{l}\text { ISRA (India) } \\
\text { ISI (Dubai, UAF } \\
\text { GIF (Australia) } \\
\text { JIF }\end{array}$ & $\begin{array}{l}=1.344 \\
=0.829 \\
=0.356 \\
=1.500\end{array}$ & $\begin{array}{l}\text { SIS (USA) } \\
\text { PИНЦ (Russia) } \\
\text { ESJI (KZ) } \\
\text { SJIF (Morocco) }\end{array}$ & $\begin{array}{l}=0.912 \\
=0.179 \\
=1.042 \\
=2.031\end{array}$ & ICV (Poland) & $=6.630$ \\
\hline
\end{tabular}

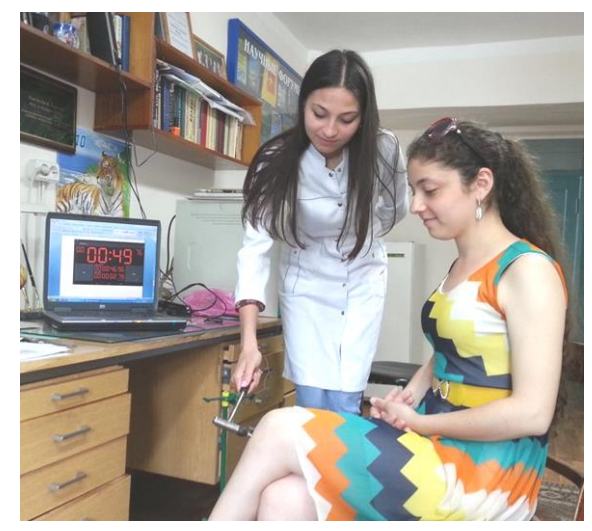

Figure 6 - The examination test photo.

On figure 5 the photo of knee-jerk reflex meter is shown. Also shown is the examination test photo (fig. 6).

The data of scale examinations of thyroid gland condition of students in the age from 16 till 18 years are presented in the graph (fig. 7). For carrying out the investigations, the methods of express diagnostics, developed by authors of present paper were used. The examinations were carried out on the group of 101 people.

After statistical processing of measurements data the randomization with the use of the criteria, established during the clinical tests of developed devices, was carried out. The obtained data are presented in the form of histograms. As a result of the investigations the circle of students, which according to the received data are possible to assume the existence of hypo function of a thyroid gland, was established. The part of such persons among those, who were examined, makes about $17 \%$.

Hyperthyroid signs were established among insignificant part of examined persons. The part of them doesn't exceed $8 \%$. Students with abnormal reflex times were recommended for hormone testing with consultation of the endocrinologist.

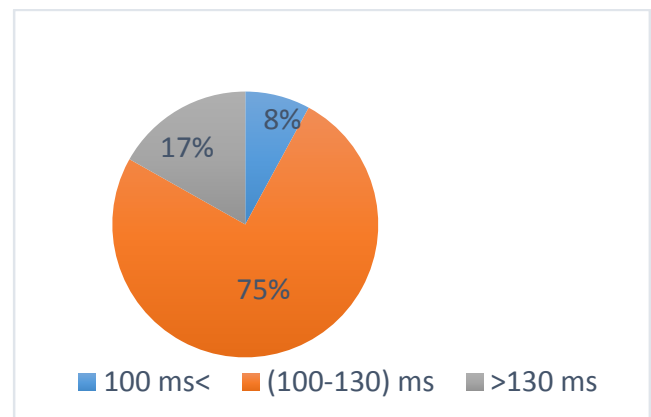

Figure 7 - The diagram of the data of scale examinations of thyroid gland condition of students.

\section{Conclusion}

A simple, cheap, and portable method is described for the measurement of the knee-reflex time. It is shown to be a reliable diagnostic aid in thyroid dysfunction and particularly in cases where clinical difficulty is present. The measurement of the knee-jerk time is a reliable test of thyroid function in pregnancy.
Present research is supported by the Ministry of Education and science of the Russian Federation. The name of the project: "A development of new method of diagnostics of thyroid gland disorders" (№ $2014 / 54$, code of the project 2405).

\section{References:}


1. Molcho J, Rechef A (1999) Electronic Measurement of Achilles Tendon Reflex. Clin. Endocrinol. (Oxf). 1999. V. 51. no. 4. pp. 429.

2. Oravec V, Oravcova K, Hnilica P, Mocikova J, Bakosova E, Sykora M (1986) Reflexometry of the Achilles Tendon and the Functional State of the Thyroid Gland in Schoolchildren with Emphasis on the Determination of the Achilles Tendon Reflex Intervals. Cesk. Pediatr. 1986. Vol. 41. № 8. pp. 459.

3. Khurana AK, Sinha RS, Ghorai BK, Bihari N (1990) Ankle Reflex Photomotogram in Thyroid Dysfunctions. J Assoc Physicians India. 1990. Vol. 38. no. 3. pp. 201.

4. Chaney WC (2013) Tendon Reflexes in Myxoedema: a Valuable Aid in Diagnosis. J. Amer. Med. Ass. 1924. Vol. 82. pp. 2013.

5. Lawson JD (1958) The Free Achilles Reflex in Hypothyroidism and Hyperthyroidism. New Engl. J. Med. 1958. V. 259. pp. 761.

6. Gilson WE (1959) Achilles Reflex Recording with a Simple Photomotograph. New Engl. J. Med. 1959. V. 260. pp. 1027.

7. Oravec V, Oravcova K, Hnilica P, Mocikova J, Bakosova E, Sykora M (2002) Reflexometry of the Achilles Tendon and the Functional State of the Thyroid Gland in Schoolchildren with Emphasis on the Marinella M.A. Recognizing Clinical Patterns: Clues to a Timely Diagnosis. Philadelphia: Hanley and Belfus. 2002. pp. 85.

8. Deguchi T, Arimura K (2005) Sensory Function Test and Achilles Tendon Reflex for the Diagnosis and Staging of Diabetic Neuropathies. Nihon Rinsho. 2005. Vol. 63. no. 6. pp. 588.

9. Burkholder DB, Klaas JP, Kumar N, Boes CJ (2013) The Origin of Woltman's Sign of Myxoedema. J. Clin. Neurosci. 2013. no. 13. pp. 40.

10. Gaydina GA, Matveeva LS, Lazareva SP (1982) Refleksometriya kak dopolnitelnyiy metod izucheniya gipotireoza // Problemyi endokrinologii. - 1982. - T. 28. - № 1. - pp. 3438.

11. Greyser AE, Blok LP (1969) Izmerenie vremeni ahillova refleksa // Klinicheskaya meditsina. 1969. - T. 47. - № 3. - pp. 72-78.

12. Robson AM, Hall R, Smart GA (1965) A Critical Evaluation of the Tendon Reflex Measurement as an Index of Thyroid Function. Postgrad. Med. J., 1965., V. 41. pp. 518.

13. Abazova ZKh, Baisiev AKh, Koumykov VK, Efendieva MK (2005) On One Method of Express-Diagnostics of Thyroid Function Abnormality // Meditsinskaya tehnika. - 2005. № 3. - pp. 8-11.

14. Abazova ZKh, Baisiev AKh, Koumykov VK, Efendieva MK (2006) Direct Method for Measuring Reflex Time of Knee Jerk in
Patients with Thyroid Pathologies // Biomedical Engineering. - 2006. - V. 40. - № 3. - pp. 117.

15. Oshhunov MM, Abazova ZH, Hatsukov BH, Kumykov VK (2013) Ob otsenke sistematicheskih oshibok pri provedenii refleksometricheskih obsledovaniy // Izvestiya Kabardino-Balkarskogo nauchnogo tsentra RAN. - 2013. - № 1. - pp. 197-200.

16. Abazova ZH, Baysiev AH, Zahohov RM, Kumykov VK, Efendieva MK (2006) Novyiy metod registratsii vremeni provedeniya ahillova refleksa pri ekspress-diagnostike patologii schitovidnoy zhelezyi // Izvestiya vyisshih uchebnyih zavedeniy. Povolzhskiy region. 2006. - № 1. - pp. 73-81.

17. Abazova ZH, Baysiev AH, Zahohov RM, Kumykov VK, Shortanova TH, Efendieva MK (2004) Diagnostika narusheniy funktsii schitovidnoy zhelezyi s pomoschyu refleksometra s pezoelektricheskim datchikom // Vestnik novyih meditsinskih tehnologiy. 2004. - № 3. - pp. 97.

18. Abazova ZH Baysiev AH, Kumykov VK, Efendieva MK (2006) Pryamoy metod izmereniya vremeni provedeniya kolennogo refleksa pri tireoidnyih patologiyah // Meditsinskaya tehnika. - 2006. - № 3. - pp. 1012.

19. Zahohov RM, Abazova ZH, Kumykov VK, Baysiev AH (2012) Skriningovyie obsledovaniya studencheskoy molodezhi s ispolzovaniem metodov ekspress-diagnostiki narusheniy funktsii schitovidnoy zhelezyi // Hirurgicheskaya praktika. - 2012. - № 1. - pp. 15-18.

20. Zahohov RM, Kumykov VK (1998) Elektrograficheskie issledovaniya funktsii schitovidnoy zhelezyi // International Journal of Immunorehabilitation. - 1998. - № 8. - pp. 150.

21. Abazova ZH, Zahohov RM, Kumykov VK, Efendieva MK (2013) Vremya refleksa kak indeks funktsii schitovidnoy zhelezyi // Mezhdunarodnyiy nauchno-issledovatelskiy zhurnal. 2013. № 10-5 (17). pp. 20-21.

22. Zahohov RM, Kumykov VK, Zahohova DR, Abazova ZH, Borukaeva IH, Hatsukov BH, Efendieva MK (2014) O metodah ekspressdiagnostiki zabolevaniy schitovidnoy zhelezyi // Fundamentalnyie issledovaniya. 2014. № 10-8. pp. 1622-1625.

23. Abazova ZH, Efendieva MK, Kumykov VK, Baysiev AH (2012) Skriningovyie obsledovaniya $\mathrm{s}$ ispolzovaniem metodov ekspress-diagnostiki narusheniy funktsii schitovidnoy zhelezyi // Uspehi sovremennogo estestvoznaniya. 2012. № 12. pp. 8-12. 